Original Article

\title{
Study of the Effects of Homeopathic Medicine Carcinosinum on Mammary Adenocarcinoma (4T1 cells) in vitro.
}

\author{
Thaís C Silva, William A Santos, Sandra AG Pinto, Vanessa Xavier, Elizabeth C Perez, Leoni V \\ Bonamin* \\ Universidade Paulista, São Paulo, Brazil. E-mail:* leonibonamin@gmail.com
}

\begin{abstract}
Background: There are few published researches about the exclusive use of Carsinosinum in several potencies to treat cancer. The name Carcinosinum refers to any homeopathic preparation of epithelial cancerous tissues and is especially indicated when there are any hereditary and familial antecedents of cancer, tuberculosis, diabetes, pernicious anemia or a combination of two or more of these diseases. Homeopathic complexes which include Conium Maculatum, Sabal Serrulata, Thuja Occidentalis and Carcinosinum can reduce in 23\% the incidence of prostate cancer in vivo and in $38 \%$ the tumor volume, compared to untreated groups. Another in vivo study revealed reduction of symptoms and increase of survival time in mice bearing Ehrlich ascitic carcinoma, after treatment with Carcinosinum 200cH. In vitro, Carcinosinum $200 \mathrm{cH}$ can increase the expression of the proapoptotic gene p53. However, mice treated with Carcinosinum $6 \mathrm{cH}$ had the highest percentage and diversity of symptoms compared to other treatments, which demonstrate the importance of homeopathic potency in pro or anti-carcinogenic action. Considering that the literature on this subject is still rare and focused on genotypic and clinical effects, the present study was proposed, with the aim of identifying the possible phenotypic changes, including viability, HER-2 expression and metastatic skills, using 4T1 cells in vitro as a model, after treatment with Carcinosinum in different homeopathic working dilutions $(12 \mathrm{cH} ; 30 \mathrm{cH} ; 200 \mathrm{cH}$ ), prepared mechanically (Denise Machine, Autic $($ ) in our laboratory $\psi$ sing ste il pyr yater, from a commercial matrix (HN Cristiano, São Paulo, Brazil) stocked ih $20 \%$ hydrodalohølic solution. The final dilutions were inserted in the culture medium in a volume equal to $10 \%$, at the time of cell seeding. The same succussioned vehicle used to prepare the medicines (70\% hydro-alcoholic solution), from the same batch and diluted 1:100 in sterile pure water, was used as control. All treated cells were cultivated in bottles of $25 \mathrm{ml}$ with cell density of $5 \times 10^{5}$ cells / $\mathrm{ml}$ and, after 24 hours of treatment, they were analyzed for the apoptosis index using the Annexin V kit and measured by the Countess® system. The morphology of the 4T1 cells was monitored by staining fixed cell smears with hematoxylineosin method. The samples were evaluated in quadruplicate and the data were analyzed by oneway ANOVA. The results obtained up to now show that the treatment with Carcinosinum 12cH produced a different pattern of cell death compared to the other treatments, with significant reduction in apoptosis index (one-way ANOVA, $\mathrm{p}=0.01$ ) and clear hydropic degeneration phenotypic pattern. The analysis of HER-2 expression and metastatic skill will be the next step of this research.
\end{abstract}

Keywords: Carcinosinum, 4T1 cells, homeopathy, in vitro model cancer, breast adenocarcinoma.

Received: March 1, 2018. Accepted: April 26, 2018. 
International Journal of High Dilution Research 2018; 17(2):22-23

Available online at www. highdilution.org

(C) International Journal of High Dilution Research.

Not for commercial purposes. 